\title{
A Study of Relations between Mughal India and the Ottoman Empire: 1556-1748
}

\author{
Umer Hameed* \\ Usman Hameed $^{* *}$ \\ Saima Umer
}

\begin{abstract}
Until the early Sixteenth Century, India was in self-imposed isolation from the outside world. However, with the development of relations between Mughals and Ottomans, India came out of this seclusion. Several factors were responsible for this historic development. The present study is, therefore, a pioneering effort. It seeks to fill a gap in the Indian and Ottoman historical literature. Fundamental questions guide this study are what factors determined Mughal policy towards the Ottoman Empire. Did the interests of the Mughal state guide it? On the other hand, was it govern by the whims, passions, and prejudices of the Mughal Emperors? How did Mughal relations with the Safavids, the Uzbeks, and the Sharif's of Mecca have any bearing on MughalOttoman relations? The present study discussed the three major aspects. The first aspect is the Mughal Empire's political and diplomatic relations with Istanbul from its beginning in 1556 to Emperor Shahjhan's deposition in 1658. The second aspect relates to the story of the Mughal-Ottoman relations from the accession of Aurangzeb in 1658 to the death of Muhammad Shah in 1748. The third aspect includes Mughal relations with the Sharif's of Mecca.
\end{abstract}

Keywords: Mughal India, Ottoman Empire, Political \& Diplomatic Relations

\footnotetext{
* National Textile University. email: umerhameeddtad@hotmail.com

** Scope Academy Lahore. email: usmanhameed1981@ gmail.com
} 


\section{INTRODUCTION}

Early Muslims knew the art of conducting negotiations with foreign countries as a substitute for war. The Prophet Muhammad had sent emissaries to Byzantium, Egypt, Persia, and an Ethiopia. However, the intent of these missions was purely religious; the rulers of these countries were invited by the Prophet to embrace Islam. The Umayyads had frequently exchanged embassies with the Byzantine Empire for negotiating peace treaties. The Abbasids also maintained diplomatic relations with their contemporary Muslim monarchs. The arrival of an embassy from a rival power was always an occasion of great fanfare in Baghdad; the brilliant reception accorded to the Byzantine ambassador in 918 bears testimony to the elaborate diplomatic protocol observed by the Abbasids. The successor states of the Abbasid Empire continued this practice and frequently exchanged envoys with each other. The hectic diplomatic activity carried on by the monarch of Darul Islam in the fourteenth and fifteenth century is evident from the mass of epistolary literature available in the collections of diplomatic correspondence as well as in the contemporary chronicles ${ }^{1}$.

In his book Foreign Policy of the Great Mughals (1967), R.C. Verma has devoted only a few perfunctory remarks to Mughal-Ottoman diplomatic relations. Moreover, these observations betray the author's lack of awareness as to the information available on this subject in the Mughal and Ottoman sources. Standard monographs on individual Mughal Emperors are also available. ${ }^{2,3,4,5,6,7}$

These, while narrating Mughal relations with Persia and Central Asia in detail, have almost totally ignored the Mughal-Ottoman relations. For instance, Professor B.P. Saksena in his excellent study of Emperor Shahjahan (1932) has devoted only three pages to the Emperor's diplomatic relations with Istanbul.

In his monumental History of Aurangzeb (in five volumes, 1912-24) Sir J.N. Sarkar has likewise spared barely two pages for Mughal-Ottoman relations. The situation is no better in Ottoman historiography. Professor Karpat's observation that "Ottoman history is the stepchild of historical studies" is especially applicable to the studies of the Ottoman Empire's relations with her contemporary Muslim states. 8 Only two short monographs on Ottoman-Persian relations are available. These cover barely 43 years of the more than four centuries of contacts between the two states. ${ }^{9,10}$

Notwithstanding the abundance of material in Turkish archives on Ottoman relations with the Uzbeks and with the Khans of Crimea, historians to date have sketched only the barest out-

\footnotetext{
${ }^{1}$ Khadduri, Majid. War and Peace in the Law of Islam. Majid Khadduri. Johns Hopkins Press, 1955.

${ }^{2}$ Rushbrook Williams, L. F. "An Empire Builder of the Sixteenth Century." (1918).

${ }^{3}$ Avasthy, Rama Shanker. The Mughal Emperor Humayun. No. 1. History Department, University of Allahabad, 1967.

${ }^{4}$ Srivastava, A. L. A Short History of Akbar the Great. Agra, 1965.

${ }^{5}$ Qureshi, Ishtiaq Husain. Akbar: the architect of the Mughul empire. No. 40. Idarah-i-Adabiyat-i-Delli, 1987.

${ }^{6}$ Saksena, B. P. "History of Shah Jahan of Dihli (Allahabad, 1932)." ff 81, no. 310: 63.

${ }^{7}$ Sarkar, Jadunath. "History of Aurangzeb." (2017).

${ }^{8}$ Karpat, Kemal H., ed. The Ottoman State and Its Place in World History: Introduction. Vol. 11. Brill, 1974.

${ }^{9}$ Kütükoğlu, Bekir. Osmanlı-Iran Siyasi Münasebetleri: 1578-1590. İstanbul Üniversitesi Edebiyat Fakültesi, 1962.

${ }^{10}$ Fleischer, C. H. (1976). Robert W. Olson, The Siege of Mosul and Ottoman-Persian Relations 1718-1743 (Bloomington: Indiana University Publications, Uralic and Altaic Series, Volume 124, 1975). Pp. 237+ xiv. \$16. Review of Middle East Studies, 10(2), 41-42.
} 
lines of these relationships. Ottoman historians have also neglected Ottoman-Indian relations for, which enough source material is not forthcoming. Professor Hilanet Bayur's Hindis Tarihi (two volumes, Ankara, 1947-1950) has devoted only a few cursory remarks to OttomanMughal relations. Standard works on Ottoman history, such as Professor Uzunrili's Osmanli Tarihi (6 vols. Ankara, 1947-1959) and Ismail Danismend's Izhali Osmanli Tarihi Kronolojisi (4 vols., Istabul, 1947-55), likewise, contain very little information on the subject under review.

\section{COLLECTION OF DATA}

It is necessary here to define the chronological limits of this study. The paucity of source material dictated that I take my evidence from a very long period, roughly $1556-1748$. Nevertheless, these dates have importance of their own. The year 1556 marks the beginning of the diplomatic relation between the Mughal and the Ottoman states, when Emperor Humayun (1530-1556) wrote his first, and his last, letter to the Ottoman Sultan. The year 1748, on the other hand, marks the termination of Mughal-Ottoman relations. It was in this year that the last Ottoman embassy to the Mughal court left Shahjahanbad, the Mughal capital, on its homeward journey to Istanbul. After 1748, there is no record of any exchange of diplomatic missions between the two sides. The background for the interaction of the Mughal Emperors, Humayun to Muhammad Shah, with their contemporary Ottoman Sultans, is provided by examining the attitude of Babur (1526-1530), the founder of the Mughal Empire in India, towards the Ottomans. This is been done to highlight the continuity or the change in Mughal policy towards the Ottomans after Babur's death.

The basic sources used in this study is classified under four headings: official documents of the Ottoman government, chronicles of the Ottoman Empire, court histories and private chronicles of the Mughal Empire, and collections of letters and diplomatic correspondence. The first category includes those documents, mainly farmans (decrees) of the imperial Ottoman government, which provide information on Ottoman-Indian relations. These decrees are recorded in a kind of official letter-book called Muhimme Defteri (Register of Important Affairs).

It contains copies of the dispatches from the Ottoman Sultans and occasionally from the Grand Wazir and Sheikh al-Islam to provincial, military and religious officials in all parts of the empire. Another set of documents, which have proven very fruitful for this study, are the Name Humayun Defteri (Register of Imperial Correspondence). Preserved in the Vekalet Archive, these registers contain copies of the Ottoman Sultan's letters addressed to foreign potentates and dignitaries; letters received from foreign monarchs and dignitaries are recorded in these registers.

The second category includes the chronicles of the Ottoman Empire written by contemporary or near-contemporary Ottoman historians; these chronicles provide supplementary information on the diplomatic exchanges between the courts of Shahjahanabad and Istanbul. Almost all the major chronicles have been used. However, two chroniclers in particular, because of their interest in Indian affairs, have been relied upon extensively: Mustafa Naima and Suleiman Ibn Khalil Izzi. Naima, the first occupant of the office of Vakanuvislik (official court chronicler) was the author of Revzat al-Hiisaeyn fi Hulasat Ahbar al-Hafikeyn.

This work, popularly known as Tarih-i-Naima and described by Professor Shaw as "a landmark in Ottoman historiography, 1"4 covers the period 1591-1660. Naima's account of the diplomatic relations between India and the Ottoman Empire during the reign of Shahjahan is very valuable. It is through Naima alone that we can know about the arrival of the Mughal 
prince Baisanghar in Istanbul to seek Ottoman aid against Shahjahan. For this study, the text edited by Zuhuri Danisman (6 vols. Istanbul, 1967-1969) is used.

Suleiman Izzi, who served as Vukanuvis from 1743-1745 and again from 1746 1753, was the author of Tarih-i-Izzi. The period covered by this chronicle extends from 1744 to 1752 . It provides firsthand information on the diplomatic exchanges between Sultan Mahmud I (1730-1754) and the Emperor Muhammad Shah (1719-1748). Izzi has copied the text of the letters exchanged between the two monarchs; the chronicler has also reproduced the petitions sent by the Mughal Nizam ul-mulk Asaf Jab I and his son Nasir Jung to the Ottoman Sultan. These letters and petitions are almost exact copies of the originals recorded in the $\mathrm{Name} \mathrm{Hu}-$ mayun Defteri. However, Izzi has not copied the confidential letter sent by Nizam ul-mulk to Mamud I, exhorting the Sultan to invade Persia. This indicates that contrary to the observation of modern scholars, the official Ottoman chronicler did not have access to all the state documents. $^{11}$

For the present study, the manuscript preserved in the British Museum (B.M. Or. 9318, transcribed in 1769) is used. Most of the major Mughal chronicles, official as well as private, are available in print. Many of these, especially those dealing with the reigns of Humayun and Akbar (1556-1605), is translated into English. Sheikh Abul Fazl's Akbar Nama is an authentic history of Akbar's reign. Though not very helpful for assessing Akbar's attitude towards the Ottoman, the chronicle does provide reliable information on the Emperor's relations with the Sharifs of Mecca. Abul Fazl's account of the Ottoman dynasty is inaccurate. This probably indicates the chronicler's lack of interest in Ottoman affairs. The chronicles of Shahjahan's reign are, however, very useful for reconstructing Mughal-Ottoman relations; Abdul Hamid Lahori's Badshah Nama and the Aml-i-Salih of Muhammad Salih Kanbu, published in the Bibliotheca Indica series, have been mainly used for this study. The latest edition of Aml-i-Salih, revised by Dr. Waheed Qureshi (3 vols. Lahore, 1967-72), has also been used. Khafi Khan's Muntakhab-ul-Lubab is the best-known private chronicle of the Mughal Empire.

Compiled in 1731, this work provides additional information on the diplomatic exchanges between the Mughals and the Ottomans. Khafi Khan's account of European piracy against Indian pilgrim and merchant ships during the reign of Aurangzeb is very useful in examining the Mughal attitude towards the problem of Haj traffic.

My references are to the Persian text published in the Bibliotheca Indica series. Extensive use has been made of the diplomatic correspondence of the period. In all, almost sixty dispatches were consulted; many of these are preserved in collections of correspondence. For the present study, Munshaat-us-Salatin has proved to be very helpful. Compiled by Ahmad Feridun Bey, Secretary to the Grand Wazir Sokullu Muhammad Pasha, it contains almost all the letters exchanged between the Mughals and the Ottomans in the seventeenth century. The text published from Istanbul in 1848-49 has been used. On the Mughal side, the most well-known collection of letters is Maktubat-i-Allami of Sheikh Abul Fazl. It contains letters written by the Sheikh to foreign potentates in the name of Emperor Akbar as well as the Sheikh's own dispatches to Mughal dignitaries. The imperial epistles sent to the Uzbek monarch Abdullah Khan Uzbek are very useful for reconstructing Akbar's attitude towards the Ottomans. The

\footnotetext{
${ }^{11}$ See for example the following observation of Professor Stanford Shaw: "The vakanuvislik was established as a separate division of the chancery of the Imperial Council, so that the court chronicler would ha e direct, immediate and continuous access to the Muhimme registers of Council decisions as well as other state papers, and he could set them down or swmnarize them before they were lost or scattered."Ibid., p. 288.
} 
text published from Lucknow in 1863 is used. The unique collection of Emperor Aurangzeb's Hasbul Hukms (decrees), dictated to his secretary.

The present study discussed the three major aspects. The first aspect is the Mughal Empire's political and diplomatic relations with Istanbul from its beginning in 1556 to Emperor Shahjhan's deposition in 1658. The contacts of the pre-Mughal Muslim states of the subcontinent with the Ottomans as well as Babur's attitude towards them is briefly outline to provide proper background to the policies of Babur's successors. The influence exercised by the events in the neighboring Safavids and Uzbek empires and of the personal whims and passions of the Mughal, monarchs on the over-all Mughal-Ottoman relations is scrutinize. The efforts made by the Ottomans to maintain friendly relations with the Mughals and the kaleidoscopic attitude of the Mughals, together with its causes, is emphasize. The second aspect relates to the story of the Mughal-Ottoman relations from the accession of Aurangzeb in 1658 to the death of Muhammad Shah in 1748. The change in the pattern of the Mughal-Ottoman relationship, which occurred in this period, is review and the factors responsible for this change is been analyzed. The downfall of the Safavids dynasty and the rise of Nadir Shah in Persia is been briefly discussed. The impact of these events on the fortunes of the Mughal and the Ottoman states and their effects on Mughal-Ottoman relations is also been appraised. The third aspect includes Mughal relations with the Sharif's of Mecca. ${ }^{12}$

Forth aspect discussed the problems of Indian Muslims going to Mecca on pilgrimage during the period under review. The major hurdle was the Portuguese blockade of the sea route to the Holy Land. The pilgrims going by the land route via Persia had to suffer the sectarian hostility of the Safavids government. In the sixteenth century the Muslims of South East Asia, who were also victims of Portuguese aggression, petitioned the Ottoman Sultan to relieve them from the Portuguese yoke. At about the same time the rulers of Central Asia requested the Porte to help them against Russian aggression. They complained that the Russian conquest of Kazan and Astrakhan had blocked the only land route to Mecca available to Central Asian pilgrims.

\section{Political \& Diplomatic Relations}

The departure of Manzade Husain Agha from India marks the end of the first phase of the Mughal-Ottoman diplomatic and political relations. It was a phase of mutual indifference, occasional outbursts of concord and harmony, and spasmodic hostility. Babur, the first Mughal, was steepe in Turkish culture. He spoke and wrote beautiful Turkish. The Emperor also admired and utilized Ottoman military tactics and methods. Yet, he remained indifferent towards the Ottomans. A staunch enemy of the Uzbeks, Babur considered the OttomanUzbek friendship as damaging to his aims and interests in Central Asia; consequently, he did not attempt to establish diplomatic relations with the Ottomans. Akbar, who followed $\mathrm{Hu}-$ mayun, not only reversed this policy, but also even demonstrated outright hostility towards the Ottomans. Akbar's foreign policy based on "real-politik." ${ }^{13}$ However, in his dealing with the Ottomans, a combination of Ottoman navy and Mughal army - could have posed serious problems for the Portuguese. Indeed, it could have curtailed, if not ended, the Portuguese

\footnotetext{
12 Al-Amr, Saleh Muhammad. The Hijaz under Ottoman rule, 1869-1914: Ottoman vali, the sharif of Mecca, and the growth of British influence. Riyad University Publications, 1978.

${ }^{13}$ Professor Aziz Ahmad's observation that diplomatic exchanges between Mughals and Ottomans continued until the end of the eighteenth century and that Haji Yusuf Agha was one of the many Ottoman envoys, who came to Delhi between 1750-1799 is incorrect. See his Studies , p. 45. Yusuf Agha had left India in 1748. His return to Istanbul has been described by Izzi in the events of 1750 (see above). It is probably to this embassy of Yusuf Agha that both Aziz Ahmad and Bernard Lewis ("The Mughals " p. 8) has referred.
} 
depredations on Indian commerce and Haj traffic. Akbar, by ignoring the potential of such a collaboration, missed a good opportunity to fulfill his oft-repeated promise of declaring jihad against the Firangis (Europeans), and thereby clearing the sea route to the Holy Cities of the Portuguese.

Jahangir's diplomacy constructed on friendship and to some extent, even dependent on Safavids Persia. This was at the expense of cordial relations with the Uzbeks and the Ottomans. He recognized the inexpediency of this policy towards the end of his reign and had to fall back upon Uzbek and Ottoman support against the Safavids. However, for the Emperor's death in 1627, Mughal-Ottoman relations would have certainly improved. Shahjahan, early in his reign, revived his father's idea of an association of Sunni powers against Persia. He was also the first Mughal to establish full-fledged diplomatic relations with the Ottomans.

Nevertheless, the Emperor's overweening ambition and arrogance coupled with his obsession with the idea of conquest of his ancestral domains wrecked his plans as well as his prestige. ${ }^{14}$ Shahjhan's military intervention in Central Asia left him isolated in the world of Islam. The Ottoman initiative in 1649 restored suspended diplomatic relations. At the time of Shahjhan's deposition in 1658, the Mughal-Ottoman relations had improved considerably. Babur and Humayun had maintained cordial relations with Persia.

In the time of Akbar, Persia was not strong enough, as it subsequently became during the reigns of Abbas Abbas II, to pose any serious threat to the Mughals and I. Akbar, therefore, never felt obliged to court the Ottomans. However, Jahangir and Shahjahan did feel imperiled by Persia and toyed with the idea of a Sunni alliance against the Safavids ${ }^{15}$.The Mughals, however, remained wedded to this policy as long as it served their immediate interest; they abandoned it when it fulfilled its primary objective and ceased to offer any dividends.

Shahjahan, for example, relinquished the policy of Sunni solidarity after the capture of Qandahar, unilaterally suspending diplomatic relations with the Ottomans. Their predilection for maintaining the territorial integrity of the Uzbek empire al o constrained them to woo the Mughals. The Ottomans seem to have been genuinely interested and sincere in their wish to befriend the Mughals. Shahjhan's acerbity and over-sensitiveness at minor discourtesies of diction in the Ottoman imperial epistles, the Ottoman moderation and large-heartedness in acknowledging their own faults graciously as well as their conciliatory messages and desire to continue the exchange of embassies without interruption demonstrate their positive approach, ardor, and probity. ${ }^{16}$ What transpired in the time of Aurangzeb (1658-1707) and his successors? Did the steady decline of the Mughal and the Ottoman empires in the late 18th century change the pattern of Mughal-Ottoman relationship? Did the collapse of the Safavid dynasty bring about any change in their priorities and strategies or in their attitude towards one another?

The last 90 years (1658-1748) of Mughal-Ottoman relations were mark by many vicissitudes. Throughout his long reign of almost fifty years, Aurangzeb had remained indifferent towards

\footnotetext{
${ }^{14}$ M.D., 153, p. 278, Evail Rajab 1161 (Middle of June, 1747). In 1762, Ahmad Shah Abdali also proposed an Ottoman invasion of Persia. But Sultan Mustafa III turned down this proposal. See Name Humayun •.• vol. 8, pp. 481-484; Ibid., pp. 485-487. Also see Hilanet Bayur, "Nadir Sah Af rin॰. "pp. 409-469.

${ }^{15}$ Hukum Namah, Royal Asiatic Society of Bengal Ms. No. 1677, ff 10b-16a, quoted by Mohibbul Hasan, History of Tipu Sultan, Calcutta, 1971 (second edition), pp. 128-130. Also see Waga-i-Manazil i-Rum, ed. Mohibbul Hasan, Asia Publishing House, 1968, pp. 1-2. This is the diary of Tipu's embassy to Turkey. It was maintained by Khwaja Abdul Qadir, the Secretary of this embassy.

${ }^{16}$ M. Hasan, History of , p. 137; Waga-i- , p. 62; Name Humayun., vol. 9, pp. 219-220.
} 
the Ottomans. His response to the Ottoman diplomatic initiative of 1690 was too lukewarm to resume friendly relations with them. The steady decline of the Safavid power, after the death of Shah Abbas II in 1666, had eased the pressure on the north-west frontier of the Mughal Empire. On the other hand, the annexation of Bijapur and Golkunda by 1687 and the execution of the Maratha ruler Shambhaji in 1689 had considerably strengthened Aurangzeb's position. Practically the entire subcontinent was now under his sway. He had never seriously entertained the idea of the re-conquest of Qandahar from the Persians and, therefore, did not need Ottoman assistance on that account.

The Ottomans were also guilty, from Aurangzeb's point of view, of not giving recognition to him when he needed it the most. All these factors seem to have guided Aurangzeb's attitude towards the Ottomans. Nonetheless, the responsibility of suspending Mughal-Ottoman diplomatic and political relations seems to lie upon Aurangzeb's shoulders. He had also stopped the exchange of embassies with Persia. "The state of diplomatic isolation" aptly remarks Professor Riazul Islam, "in which Aurangzeb left the Mughal Empire was by no means enviable." ${ }^{17}$

Farrukhsiyar attempted to break this diplomatic isolation of the Mughal Empire. He sent embassies to Istanbul and Isfahan. However, his efforts to revive the long-suspended MughalOttoman relations met with little success. His letter to Sultan Ahmad III did not create a favorable impression on the Ottoman court. In this period, the Ottomans were also preoccupied with protecting their European territories from the Austrian threat.Moreover, by 1716, when the Mughal ambassador arrived in Istanbul, the downfall of the Safavid dynasty had become an established fact.

Hence, the Ottomans did not feel obliged to foster close relations with the Mughals. Ahmad III, therefore, did not send a return embassy to Istanbul. He remained content with a friendly reply to Farrukhsiyar's letter. Farrukhsiyar's death in 1719 doomed any chance of further cultivation of Mughal-Ottoman relations. ${ }^{18}$

Early in his reign, Muhammad Shah exchanged epistles with Sultan Ahmad III. However, the real incentive for the establishment of closer ties came with the rise of Nadir Shah in Persia, who was destined to prove equally perilous to both Mughals and Ottomans. Both exhibited profound concern and anxiety to eliminate the new Persian peril. Hence, the Ottomans welcomed Muhammad Shah's overtures for a Mughal-Ottoman alliance against Persia. Several embassies and epistles were exchange between the two sides. Shahjahanabad Istanbul axis had come into existence. Muhammad Shah had, thus, the satisfaction of bringing the Mughal Empire back into the mainstream of the Islamic world; by the time of his death, MughalOttoman relations had improved considerably. This, however, was the last flicker of the lamp; after 1748, these relations abruptly came to a standstill. As far as the Ottomans were concerned, for all practical purposes, the Mughal Empire had passed into history. ${ }^{19}$

The second phase of Mughal-Ottoman relations was also mark by a change in the pattern of their relationship. This change triggered the decline of the Safavid dynasty in Persia and in-

\footnotetext{
${ }^{17}$ Riazul Islam, Indo-Persian , p. 134.

18 13Bayur, "Mysore Sultani, " p. 651; Mahmud Husain (ed.), !. History of Freedom Movement, Karachi, 1957, vol. I, pp. 488-489; M Hasan, History of . pp. 295-296. It should be mentioned here that the Nawabs of Arcot had also sent envoys to Istanbul. See Maghrebi, "Ottoman-Gujarat Relations," p. 185, Note 7.

${ }^{19}$ Name Humayun , vol. 9, pp. 360-362. Sultan Selim III had also contemplated sending an embassy to Tipu. A letter was drafted for this purpose on June 8, 1799 (See Ibid., pp. 388-389). Tipu had, however, already died on May 4, 1799 (History of , pp. 317-318). Probably, the letter was never dispatched.
} 
creased pressure of European powers on the western frontier of the Ottoman Empire. The focus of Ottoman strategies had now shifted from the Shia menace to Islam to the threat posed by the Christian powers. Suleiman I's letter to Aurangzeb and Ahmad III's epistle to Farrukhsiyar does not dwell upon the Shia peril at all. They focus mainly on the theme of protecting the 'land of the Faithful' from the aggression of the Christian powers. Suleiman II even solicited Aurangzeb's support against the Christians and urged him to wage holy war against them. Farrukhsiyar's letter to Ahmad III, likewise, is conspicuous by its omission of any reference to Persia.

Persia, nevertheless, came back to play an important role in shaping the Mughal-Ottoman relations. Nadir Shah's invasion of India and his aggressive designs against Ottoman Empire made her an object of fear, suspicion, and hostility in the eyes of Mughals and Ottomans alike. Ambassadors began to travel between Shahjahanabad and Istanbul; highly conciliatory and friendly letters were exchange. In these, the ancient accord between the two houses was recall; sectarian unity and the identity of faith were assert repeatedly. Both sides also pledged to undertake Jihad against kufr (infidelity) and tyranny. The Ottoman-Persian treaty of 1746, the assassination of Nadir Shah in 1747, and the death of Muhammad Shah in the following year, put an end to this frantic diplomatic activity.

Emperor Ahmad Shah (1748-1754) did not care to send a letter, through Haji Yusuf Agha, to the Ottoman Sultan. There is no record of any Ottoman congratulatory mission on the accession of Ahmad Shah either. Diplomatic exchanges between Mughal India and the Ottoman Empire had reached a dead One noteworthy development in this period was the exchange of letters between ministers and other notables of the two empires. This was by no means an unprecedented phenomenon. Letters had earlier been exchange between Shahjahan's Wazir and his Ottoman counterpart in the 1640s.

\section{Mughal Relations with the Sharifs of Mecca}

Mughal relations with the Sharifs of Mecca were mark by many vicissitudes. Babur, the first Mughal, was cognizant of the influence wielded by the Sharif of Mecca in the Islamic world. Hence, he took care to propitiate the Sharif. He sent Naizur to Mecca after his victory in the battle of Panipat. Babur also displayed his zeal for the Holy Land by sending a copy of the Quran transcribed by himself. Of Humayun's contacts with the Sharifs of Mecca, during his stormy reign of sixteen years, we have no knowledge. He, however, deported two of his brothers to Mecca; the Emperor, thereby, became unconsciously responsible for setting up a dangerous precedent. Henceforth all of his successors sought to use Mecca as a convenient place for banishing political offenders. It was only in the eighteenth century, when the later Mughal Emperors no longer had the power to enforce their will on their unruly subordinates that they gave up this practice. Akbar began his reign by establishing close links with the Hijaz. He sent gorgeous gifts to the Sharif of Mecca. The Emperor initiated the policy of organizing ar1 annual Haj caravan to Mecca. He also began to appoint a royal Mir Hai. Every year, to represent him in the Raj. Nevertheless, Akbar soon got involved in an unfortunate broil with the Ottomans over the affairs of the Indian pilgrims. The disbursement of the sadagat sent by the Emperor was ban. The Sharif was order to expel the Indian pilgrims from Mecca, including the women of his household, after the Haj season. This, coupled with Akbar's own religious policies, led to a temporary breach in Mughal-Hijaz relations.

Jahangir did not attempt to break this deadlock. Sharif Idris's initiative in 1607 did not make any impression on him; the Emperor did not dispatch a return embassy to Mecca. Only twice in his long reign of 22 years did Jahangir send gifts to the Sharif of Mecca. The Emperor did 
not revive the practice of organizing annual Haj caravan to Mecca. Given Jahangir's Luke warmness to everything religious, his indifferent attitude towards the Sharif of Mecca is not surprising. With the accession of Shahjahan to the throne, the situation began to change. He regularly sent emissaries to the Holy Cities with splendid gifts in cash as well as in kind. Shahjahan started the practice of sending Indian merchandise to Mecca; the proceeds of these goods, along with the profit, which accrued from this transaction, were distributed between the Sharif and the needy of the Holy Cities. The Emperor revived the organization of the annual Haj caravan to Mecca. He also enrolled a former envoy of the Sharif of Mecca, to his court, in the imperial service. By the time of Shahjahan's deposition in 1658, the MughalSharifian relations had considerably improved. ${ }^{20}$

During the first three decades of his reign, Aurangzeb maintained cordial relations with Mecca. Several diplomatic missions arrived from Mecca; the Emperor reciprocated with equally warm and affable gestures. Imperial agents, carrying subventions for the Sharif and their inhabitants of the Holy Cities, visited Mecca at regular intervals. Haj caravans with royal Mir Baj continued to sail for Mecca for the annual pilgrimage. In the later years of his reign, however, the avarice of the Sharifs of Mecca disillusioned Aurangzeb. He stopped entertaining the Sharif's request for pecuniary aid and suspended official relations with Mecca altogether. Relations were restore after Aurangzeb's death. Bahadur shah, Farrukhsiyar, and Muhammad Shah received embassies from Mecca. They also sent gifts to the Sharifs. Farrukhsiyar even sanctioned an annual subsidy of 100,000 rupees for the Sharif. During the reign of Muhammad Shah, a permanent representative of the Sharif began to reside in Surat.

At the time of Muhammad Shah's death in 1748, the Mughal-Sharifian relations were steady and stable. Notwithstanding the religious prestige enjoyed by the Sharifs, the Mughals did not treat them as their equals. They never sent a full-fledged imperial mission to Mecca. This is the impression we get from the narrative of the Mughal chroniclers. While designating the messengers of the Sharifs as ambassadors, these chroniclers invariably describe the Mughal officials going to Mecca as imperial agents or emissaries. They style the letters of the Sharifs, brought either by Sharifian envoys or by the imperial agents, not as Murasla or Maktub, terms which stand for correspondence between equals, but rather as arzdasht, which designates a letter addressed by an inferior to a superior $1 .{ }^{21}$

Akbar's letter to Sharif Abu Numay II is a good example of the air of superiority assumed by the Mughal Emperors, while addressing the Sharifs. The letter is authoritative in tone, assures the Sharif of the unlimited imperial favours, and commands him to carry out the royal instructions. The Sharifs, on the other hand, did not object to this unobtrusive treatment. They were willing to play the role of a subaltern as long as the Mughals were ready to grease their palm.

Relations with the Sharifs of Mecca did not exercise much influence in shaping the MughalOttoman relations. Mughal policy towards the Ottoman Empire was largely govern by the developments in Persia. In this, the Sharifs of Mecca had hardly any say. Likewise, the Sharifs, though powerful in their own realm, could in no way influence decisions, whether in

\footnotetext{
${ }^{20}$ Ibid., p. 271; T.A., III, p. 472; M.T., II p. 217.

${ }^{21}$ For the Haj caravans of Egypt and Syria, see Abdullah Ankawi, "The Pilgrimage to Mecca in Mamluk Times," Arabian Studies, Ed. R.B. Serjeant and R.L. Bidwell, London, 1974, vol. I, pp. 146-170. According to Nizamuddin Ahmad, Akbar was the first Muslim ruler to send a caravan from Hindustan to Mecca. He writes: "Up to the time of the rising of the Sun of this Sovereign [Akbar], no other monarch had such an honour and grandeur, that he should sent a caravan from Hindustan to Mecca the revered, and should remove the custom of need from the poor of that honoured place." T.A., II, p. 472.
} 
favor or against the Mughals, at the Ottoman court. Only once did the developments in Hijaz, have an adverse effect on the Mughal-Ottoman relations. This was the row over the activities of the Indian pilgrims in Mecca, during the reign of Akbar, which led to hostility between two sides. However, this was solely Akbar's handiwork. He overreacted to a minor incident and blew it out of proportion. For this, neither the Sharif of Mecca nor the Ottoman Sultan could be held responsible. After this incident, the Indian pilgrims seem to have kept themselves out of trouble. Henceforth the relations between these two premier Muslim States followed its usual course. ${ }^{22}$

\section{CONCLUSION}

Babur, the first Mughal, had his eyes fixed on Uzbek Central Asia, his ancestral domain, as an area of expansion. He, therefore, regarded Ottoman-Uzbek alliance as damaging to his aims and interests in that region. This made him a natural enemy of the Ottomans; hence, the Emperor did not attempt to establish formal diplomatic relations with Istanbul. He also did not show any inclination to acknowledge the Ottoman claim to the Khilafat of Islam. During the early years of his reign, Humayun also remained indifferent towards the Ottomans. Elated by his conquest of Gujarat and Bengal, he regarded the Ottoman Empire as an inferior power. During his days of exile, he did not seek Ottoman support against his Afghan adversary. However, Humayun was not hostile to the Ottomans.

After restoration to the Indian empire, the Emperor displayed a genuine desire to establish diplomatic relations with the Ottomans on a permanent basis. He cordially welcomed the Ottoman admiral Sidi Ali Reis, complimented the admiral for his military and literary talents, and offered him a high position in the Mughal government.

The Emperor wrote a very friendly letter to Suleiman the Magnificent. He also acknowledged the Sultan as Khalifa. However, for the sudden death of Humayun in 1556, Mughal-Ottoman relations would have considerably improved. Akbar abandoned Humayun's conciliatory policy altogether. Sultan Suleiman's failure to send a congratulatory embassy on his accession coupled with the Emperor's own military achievements and the rapid expansion of his empire were probably responsible for Akbar's lukewarm attitude towards the Ottomans. The row over the activities of the Indian pilgrims in Mecca in the late 1570's and early 1880's also produced considerable tension between Akbar and the Ottomans.

The rise of the Uzbek power under Abdullah Khan Uzbek and the Ottoman support for the Khan's expansionist designs in Khurasan and Badakhshan also wade the Emperor highly skeptical of a lasting Mughal-Ottoman rapprochement. Akbar even entertained the idea of invading Ottoman territories in collusion with the Portuguese.

Far from acknowledging the Ottoman claim to Khilafat, the Emperor made a bold bid to get himself recognized as the temporal leader of his Muslim subjects. However, Akbar's policy towards the Ottoman was unrealistic and unsound. Friendship with the Ottomans would have obliged the Uzbeks to give up the anti-Mughal propaganda, which they had unleashed in the northwestern provinces of the Mughal Empire. Mughal-Ottoman collaboration would have paid dividends in other areas of mutual interests. More than anything else, it would have

\footnotetext{
22 17A.H., III, p. 306. For an account of Mir Abu Turab's return from the Hijaz with an impression of the Prophet's footprint and of Akbar's reception to it, see A.N., III, pp. 410-412; T.A. II, pp. 557-558; M.T., II, pp. 320-321; Mirat-iAhmadi, I, pp. 138-139.
} 
saved the Indian Muslim pilgrims from the suffering and humiliation, which they had to endure at the hands of the Portuguese freebooters.

Shahjahan established full-fledged diplomatic relations with Istanbul. He also revived his father's idea of a Sunni alliance against Persia. However, this alliance did not materialize; the Emperor's invasion of Central Asia wrecked the chances of its fruition. The invasion even led to the suspension of Mughal-Ottoman relations. Shahjahan also assumed the title of Amir alMuminin, thereby showing his disregard for the Ottoman claim to Khilafat. Sultan Muhammad IV's initiative in 1649 broke the diplomatic deadlock and relations between Shahjahanabad and Istanbul was resume. Henceforth embassies were exchange between the two sides at regular intervals. At the time of Shahjahan's deposition in 1658, Mughhal-Ottoman relations had improved considerably. Aurangzeb gave up his father's policy of friendly alliance with the Ottomans. During his long reign of almost half a century, he remained indifferent towards them. Sultan Suleiman II's effort to revive the Istanbul-Shahjahanabad axis made no impression on him. It is indeed surprising that though the Emperor contemplated an alliance with the Corsairs of Masqat for combating piracy in Indian waters, he did not seek the help of the Ottomans to deal with this problem.

Like his great-grandfather, Aurangzeb failed to perceive that a joint Mughal-Ottoman campaign against the European freebooters would have curtailed, if not ended, the European brigandage against his pilgrim ships. The Emperor's policy towards the Ottomans, thus, leaves much to be looked-for. Diplomatic relations with Istanbul were resume after Aurangzeb's death. Farrukhsiyar sent a good will embassy to the court of Sultan Ahmad III. The Sultan responded with a friendly reply but did not dispatch a return embassy to Shahjahansbad. It was not until the rise of Nadir Shah, who had provided dangerous for both Mughals and Ottomans, in the 1730's that the real need for closer ties between the two states was felt. Several embassies were exchange. Highly conciliatory letters, underscoring the necessity for making common cause against the Persian 'heretic,' were penned. Emperor Muhammad Shah also acknowledged the Ottoman Sultan as khalifa. It was, however, the last flicker of the lamp. The rapid disintegration of Mughal Empire after Muhammad Shah's death made further advancement of Mughal-Ottoman relations practically impossible. After 1748, there is no record of any exchange of diplomatic missions between the two sides. The ShahjahanabadIstanbul axis had passed into history.

\section{Factors of amity Between the Mughals and the Ottoman}

Primarily was the community of faith and the identity of sect; both Mughals and Ottomans were Sunni. In their diplomatic correspondence, the sovereigns of both houses vied with each other in displaying their sectarian prejudice and their enthusiasm for Sunni solidarity.Safavid Persia was the main target of this orthodox tirade. They condemned the Safavids as kafir and mulhid (one who swerves from the true path), ridiculed them as Redheads and Zindigs (misbelieving hypocrites), and exhorted each other to "demolish the precepts of heresy and misbelief." They also styled each other "annihilator of mulhids and rafizis (schismatics)" and "supporter of the dominion of the Sunnis and breaker of the head of the Shias." However, vocal in their avowal to Sunni solidarity, the Mughals never used it as a guiding light of their policy towards the Ottomans. They invoked it at the time of their conflict with Persia and abandoned it as soon as it had served its purpose. The Mughals as a convenient tool calculated to serve their personal interests but not as an ideology thus used the theme of sectarian unity. It is, therefore hardly surprising that the oft-repeated proposal of Sunni alliance against Persia could never materialize. 
Safavid Persia was a menace to the Mughals as well as to the Ottomans; both powers had a common defense problem against the Persians. In the seventeenth century, Safavid designs against Qandahar and Baghdad had drawn the two sides closer. In the Nevertheless, the Mughal-Ottoman accord on the Persian question exercised only a transient influence on Mughal-Ottoman relations. The Mughals remained wedded to the policy of friendly alliance with the Ottomans as long as Persia posed a threat to them. Once the Safavid power declined and the threat from Persia disappeared, the Mughals quickly abandoned their pro-Ottoman posture. From time to time, they also maintained active and cordial relations with the Safavids.

\section{Factors of conflict Between the Mughals and the Ottoman}

Among the factors of conflict, the foremost was Ottoman friendship with the Uzbeks, whom the Mughals considered as their principal foe. Mughal-Uzbek enmity was traditional. One Emperor Shahjahan son's, did invade Mawara-an-nahr; the invasion, however, turned out to be the greatest failure of Shahjahan's career. In addition to territorial rivalry, there were a few other areas of conflict between the Mughals and the Uzbeks. The Uzbek presence in the neighborhood of the Mughal province of Kabul was a thorn in the Mughal flesh. The Mughals were extremely conscious of their ancestry from Timur. Proud of the achievements of Timur, they considered all contemporary Muslim sovereigns, ruling in the erstwhile domains of Timur, as inferior to them. Jahangir believed that the Mughals had a claim upon Ottoman gratitude because of Timur's generosity in restoring Sultan Musa challenged to the domains of his vanquished father. Even the fugitive Mughal prince Baisanghar, who had taken refuge in Istanbul in 1632, did not hesitate to brag about his illustrious descent. The Ottomans, on the other hand, were proud of their own lineage and conscious of their ancestor's services to Islam. In their eyes, Timur was nothing but an upstart. Ottoman chroniclers have generally adverted to Timur with great contempt; 16 Naima has even denounced him as a usurper. This "war of lineage" was naturally very irritating to the sovereigns of both houses and often caused considerable unpleasantness between them.

\section{CONCLUSION}

Mughal relations with the Sharifs of Mecca were mark by many vicissitudes. Babur, the first Mughal, was cognizant of the influence wielded by the Sharif of Mecca in the Islamic world. Hence, he took care to propitiate the Sharif. He sent nuzur to Mecca after his victory in the battle of Panipat. Babur also displayed his zeal for the Holy Land by sending a copy of the Quran transcribed by himself. Of Humayun's contacts with the Sharifs of Mecca, during his stormy reign of sixteen years, we have no knowledge. He, however, deported two of his brothers to Mecca; the Emperor, thereby, became unconsciously responsible for setting up a dangerous precedent.

Henceforth all of his successors sought to use Mecca as a convenient place for banishing political offenders. It was only in the eighteenth century, when the later Mughal Emperors no longer had the power to enforce their will on their unruly subordinates that they gave up this practice.

Akbar began his reign by establishing close links with the Hijaz. He sent gorgeous gifts to the Sharif of Mecca. The Emperor initiated the policy of organizing ar1 annual Haj caravan to Mecca. He also began to appoint a royal Mir Hai. Every year, to represent him in the Raj. However, Akbar soon got involved in an unfortunate broil with the Ottomans over the affairs of the Indian pilgrims. The disbursement of the sadagat sent by the Emperor was ban. The 
Sharif was ordered to expel the Indian pilgrims from Mecca, including the women of his household, after the Haj season. This, coupled with Akbar's own religious policies, led to a temporary breach in Mughal-Hijaz relations.

Jahangir did not attempt to break this deadlock. Sharif Idris's initiative in 1607 did not make any impression on him; the Emperor did not dispatch a return embassy to Mecca. Only twice in his long reign of 22 years did Jahangir send gifts to the Sharif of Mecca. The Emperor did not revive the practice of organizing annual Haj caravan to Mecca. Given Jahangir's lukewarmness to everything religious, his indifferent attitude towards the Sharif of Mecca is not surprising. With the accession of Shahjahan to the throne, the situation began to change. He regularly sent emissaries to the Holy Cities with splendid gifts in cash as well as in kind. Shahjahan started the practice of sending Indian merchandise to Mecca; the proceeds of these goods, along with the profit, which accrued from this transaction, were distributed between the Sharif and the needy of the Holy Cities. The Emperor revived the organization of the annual Haj caravan to Mecca. He also enrolled a former envoy of the Sharif of Mecca, to his court, in the imperial service. By the time of Shahjahan's deposition in 1658, the MughalSharifian relations had considerably improved.

During the first three decades of his reign, Aurangzeb maintained cordial relations with Mecca. Several diplomatic missions arrived from Mecca; the Emperor reciprocated with equally warm and affable gestures. Imperial agents, carrying subventions for the Sharif and their inhabitants of the Holy Cities, visited Mecca at regular intervals. Haj caravans with royal Mir Baj continued to sail for Mecca for the annual pilgrimage. In the later years of his reign, the avarice of the Sharifs of Mecca disillusioned Aurangzeb. He stopped entertaining the Sharif's request for pecuniary aid and suspended official relations with Mecca altogether.

After Aurangzeb's death, relations were restore. Bahadur shah, Farrukhsiyar, and Muhammad Shah received embassies from Mecca. They also sent gifts to the Sharifs. Farrukhsiyar even sanctioned an annual subsidy of 100,000 rupees for the Sharif. During the reign of Muhammad Shah, a permanent representative of the Sharif began to reside in Surat.At the time of Muhammad Shah's death in 1748; the Mughal-Sharifian relations were steady and stable. Notwithstanding the religious prestige enjoyed by the Sharifs, the Mughals did not treat them as their equals. They never sent a full-fledged imperial mission to Mecca. This is the impression we get from the narrative of the Mughal chroniclers. While designating the messengers of the Sharifs as ambassadors, these chroniclers invariably describe the Mughal officials going to Mecca as imperial agents or emissaries. They style the letters of the Sharifs, brought either by Sharifian envoys or by the imperial agents, not as Murasla or Maktub, terms which stand for correspondence between equals, but rather as arzdasht, which designates a letter addressed by an inferior to a superior. Thirty eight (38) Akbar's letter to Sharif Abu Numay II is a good example of the air of superiority assumed by the Mughal Emperors, while addressing the Sharifs. The letter is authoritative in tone, assures the Sharif of the unlimited imperial favours, and commands him to carry out the royal instructions. The Sharifs, on the other hand, did not object to this unobtrusive treatment.

They were willing to play the role of a subaltern as long as the Mughals were ready to grease their palm.139 Viewed from this perspective the Mughal-Sharfian relations could at best be describe as a kind of patron-client relationship. Relations with the Sharifs of Mecca did not exercise much influence in shaping the Mughal-Ottoman relations. Mughal policy towards the Ottoman Empire was largely govern by the developments in Persia. In this, the Sharifs of Mecca had hardly any say. Likewise, the Sharifs, though powerful in their own realm, could in no way influence decisions, whether in favour or against the Mughals, at the Ottoman 
court. Only once did the developments in Hijaz, have an adverse effect on the MughalOttoman relations.

This was the row over the activities of the Indian pilgrims in Mecca, during the reign of Akbar, which led to hostility between two sides. However, this was solely Akbar's handiwork. He overreacted to a minor incident and blew it out of proportion. For this, neither the Sharif of Mecca nor the Ottoman Sultan could be held responsible. After this incident, the Indian pilgrims seem to have kept themselves out of trouble.

\section{REFERENCES}

Al-Amr, Saleh Muhammad. The Hijaz under Ottoman rule, 1869-1914: Ottoman vali, the sharif of Mecca, and the growth of British influence. Riyad University Publications, 1978.

Avasthy, Rama Shanker. The Mughal Emperor Humayun. No. 1. History Department, University of Allahabad, 1967.

Fleischer, C. H. (1976). Robert W. Olson, The Siege of Mosul and Ottoman-Persian Relations 1718-1743 (Bloomington: Indiana University Publications, Uralic and Altaic Series, Volume 124, 1975). Pp. 237+ xiv. \$16. Review of Middle East Studies, 10(2), 41-42.

Karpat, Kemal H., ed. The Ottoman State and Its Place in World History: Introduction. Vol. 11. Brill, 1974.

Khadduri, Majid. War and Peace in the Law of Islam. Johns Hopkins Press, 1955.

Kütükoğlu, Bekir. Osmanlı-Iran Siyasi Münasebetleri: 1578-1590. İstanbul Üniversitesi Edebiyat Fakültesi, 1962.

Qureshi, Ishtiaq Husain. Akbar: the architect of the Mughul Empire. No. 40. Idarah-iAdabiyat-i-Delli, 1987.

Rushbrook Williams, L. F. "An Empire Builder of the Sixteenth Century." (1918).

Saksena, B. P. "History of Shah Jahan of Dihli (Allahabad, 1932)." ff 81, no. 310: 63.

Sarkar, Jadunath. "History of Aurangzeb." (2017).

Srivastava, A. L. A Short History of Akbar the Great. Agra, 1965. 